\title{
高周波誘導熱プラズマ初期点火時の誘導コイル負荷 インピーダンスと高周波インバータの過渡応答特性
}

\author{
正員上杉 喜彦* 学生員 鵜飼 洋史 $* *$ \\ 学生員 M. A. Razzak ${ }^{* *}$ 正 員 高村 秀一 **
}

\section{Transient Response of the Induction Coil Loading Impedance and rf Inverter System in the Initial Startup Phase of rf Induction Thermal Plasmas}

Yoshihiko Uesugi*, Member, Hiroshi Ukai**, Student Member, M. A. Razzak**, Student Member,

Shuichi Takamura**, Member

\begin{abstract}
Generation and sustainment of rf induction thermal plasmas in atmospheric pressure range require a high voltage in the initial startup phase and a high rf power during the steady state sustainment phase. The high rf electrostatic filed induced between induction coil conductor wound around a glass discharge tube generates surface electrostatic discharges in which the discharge current flows through the dielectric glass tube. After several hundreds microseconds the electrostatic discharges grow sufficiently to transfer to a volumetric electromagnetic discharge which is maintained by the inductive electric field. During this discharge mode transition, the loading impedance of the induction coil changes significantly. This loading impedance change of the induction coil leads a deviation from a series resonance condition of the LCR output circuit including the induction coil, which strongly affects the output characteristics of a semiconductor if inverter power supply. In this paper transient response of the induction coil impedance in the initial startup phase of the rf thermal plasma generation is studied experimentally. Dynamic interactions of the rf inverter power supply with generated rf plasmas are also investigated and strong deterioration of the inverter output efficiency is found experimentally. Preliminary frequency tracking experiments show a successful improvement of the inverter output efficiency and absorbed rf power in the generated plasma.
\end{abstract}

\section{キーワード : 高周波誘導熱プラズマ，高周波インバータ，誘導コイル，高周波静電放電，誘導放電，大気圧放電}

Keywords: rf induction thermal plasmas, rf inverter, induction coil, rf electrostatic discharges, electromagnetic discharges, atmospheric pressure discharges

\section{1. まえがき}

大気圧領域の直流あるいは交流アーク放電で生成される 熱プラズマは，光れ自身が有する高熱流を利用した金属の 溶融・精練，有害物質の熱分解・無害化処理，機能性薄膜， 微粒子生成等の産業応用が広くなされている(1) (3)。一方， 高周波誘導放電で生成される誘導熱プラズマは，

(i) 無電極放電で電極損耗が無く，プラズマへの不純物 混入が少ない

(ii）プラズマ動作ガスの選択肢が広い

\footnotetext{
* 金沢大学自然科学研究科

T 920-1192 金沢市角間町

Graduate School of Natural Science, Kanazawa University

Kakuma-cho, Kanazawa 920-1192

** 名古屋大学大学院工学研究科

T 464-8603 名古屋市千種区不老町

Graduate School of Engineering, Nagoya University

Furo-cho, Chikusa-ku, Nagoya 464-8603
}

(iii）大容量プラズマの生成が可能

(iv) 熱プラズマ生成効率が高い

などの利点も多く，熱プラズマの応用範囲をより拡大でき る可能性を有しており，これまでに大気圧領域での誘導プ ラズマの応用は有害フロンの熱分解処理, 機能性超微粒子 生成, 誘導放電プラズマを利用した微量元素分析等に応用

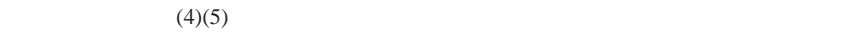
プラズマの基礎特性や弚のプラズマプロセッシングへの応 用に関する研究が広くなされていることと対照的に，大気 圧領域で生成される誘導熱プラズマの基礎物性や午の応用 に関する実験研究は少ないのか現状である。大気圧領域の 誘導熱プラズマの応用研究を困難にする要因として，

(i ) 大気圧領域での放電開始と光の維持には, 高い高周 波電界と大電力高周波源を必要とすること。特に， 大容量誘導熱プラズマ (プラズマ径〜 $50 \mathrm{~mm}$, プラ ズマ長〜 200mm) を数 $\mathrm{MHz}$ 以下の低い周波数帯で 生成・維持する場合, $10 \mathrm{~kW}$ を越える高い高周波電 
力を必要としていること (4)。

(ii) 大気圧誘導プラズマの産業応用には, 高い生成効率 や装置の運転・保守の簡便さ等が要求されるが, 現 状では大気圧領域の誘導熱プラズマの生成・維持機 構の詳細や誘導熱プラズマの高効率生成に関する研 究が十分なされていないこと。

(iii) 石英ガラス管等の誘電体放電管の内部に誘導熱プラ ズマを生成・保持することから，弚の機械的・熱的 強度が脆弱であること。

等が挙げられる。

本論文は, 半導体高周波インバータを用いた高周波誘導 熱プラズマ生成に関する研究 ${ }^{(6)}$ ( 8$)$ の中で, 特に高周波 誘導熱プラズマ初期点火から熱プラズマに成長する過程に おける誘導コイルインピーダンス変化と光れに伴う高周波 インバータ電源の過渡応答特性について実験的に調へ，大 気圧誘導熱プラズマの高効率生成手法の検討を行ったもの である。従来の高周波誘導熱プラズマに関する研究では誘 導熱プラズマの生成と安定維持が主たる研究課題であり, 熱プラズマ放電形状と最適駆動周波数やガス導入法等が数 值解析や実験により詳細に調べられているものの ${ }^{(5)}$, 誘 導熱プラズマ生成における初期静電放電から誘導放電への 移行過程や放電形態の変化に伴う誘導コイル負荷インピー ダンスの動的変化と光れによる高周波インバータ電源の発 振特性への影響等に関する実験研究は例がない。本論文の 構成として，第 2 章で実験に用いた誘導熱プラズマ装置と 高周波インバータ電源の特性を述べる。第3章において， 誘導熱プラズマ生成時における可視高速カメラによる画像 解析と誘導コイルインピーダンス過渡応答測定結果につい て述べる。最後に，まとめを第 4 章に示す。

\section{2. 半導体高周波インバータを用いた誘導熱} プラズマ発生装置

〈2. 1〉SITインバータ電源と誘導プラズマトーチ

先に述べたように大容量高周波誘導プラズマの生成・ 維持には, 周波数帯域: $100 \mathrm{kHz} \sim 100 \mathrm{MHz}$, 出力 : $10 \mathrm{~kW}$ 〜 $1 \mathrm{MW}$ の大出力高周波電源が用いられ, 弚の電源とし て，大出力が容易に得られることから自励式または他励 式の真空管電源が広く利用されてきた。これらの大出力 真空管式高周波電源は，10kV 級の高電圧電源を用いて高 周波機器も大型となり，熱プラズマに関する基礎実験を 困難にしていた要因の一つとなっている。これに対して， 近年進歩が著しい高周波パワー素子を用いた半導体イン バータ電源は, 現状では発振周波数が〜数 $\mathrm{MHz}$ 以下と限 られるものの, 数百 $\mathrm{V}$ の低圧電源で数十 $\mathrm{kW}$ の高周波出 力を 85 〜 90\% の高効率で得られるという特徵を有してお り，高効率高周波誘導熱プラズマシステムをコンパクト に構成することを可能にしている。本研究では, インバー タのスイッチング素子として静電誘導トランジスタ (Static Induction Transistor : SIT) を用いて，図 1 に示すような誘 導熱プラズマ生成用高周波システムを構成している(9)(10)。
SIT および高周波インバータ電源の主な仕樣を表 1 に示 す。本インバータ電源は, 4 個の SIT 素子を用いたフルブ リッジユニットを 6 台並列接続して, 定常出力 $20 \mathrm{~kW}$ を達 成している。DC-DC コンバータの直流出力を定電圧また は定電流制御することでインバータ高周波出力を制御し， 発振周波数は SIT ゲート駆動周波数を TTLレベルで制御 することで $0.2 \sim 2 \mathrm{MHz}$ の間で可変としている。DC-DC コンバータの出力電圧と電流は, 内蔵された分圧器およ び DCCT により測定し，インバータ高周波出力電圧と電

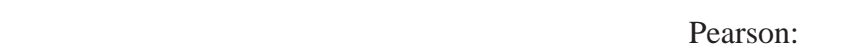
デル 1025,110$)$ により測定している。高周波誘導熱プラ ズマ生成の場合, 高周波電源を定電流あるいは定電力モ一 ドで運転することが多い。本実験では, SIT インバータ電 源の DC 部である DC-DC コンバータを定電流運転し， SIT インバータ出力電流を一定に維持する運転モードを採用し て実験を行った(なお，今回の実験に用いたSIT 素子は， 大容量, 高速スイッチング, 低損失といった優れた特徵を 有しているものの, ゲート駆動回路の複雑さから応用例が 少なく, 現在, 生産中止となっている)。

誘導熱プラズマ生成に用いるトーチの模式図および誘 導コイル負荷回路を谷れ光れ図 2 , 图 3 に示す。実験に用

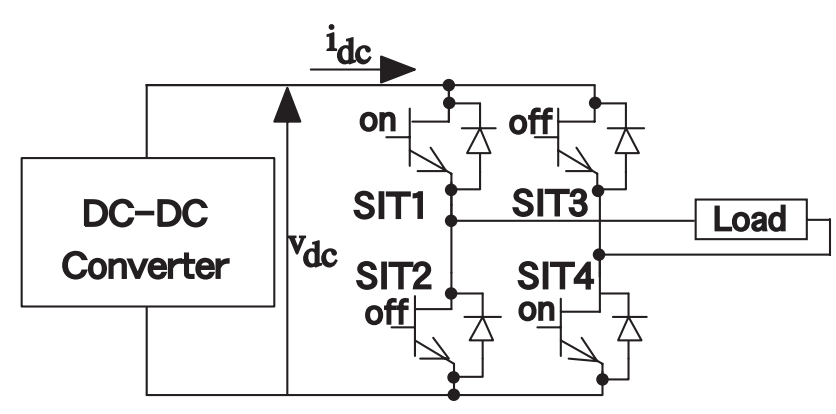

図 1 SIT インバータの主回路構成

Fig. 1. Main circuit of SIT inverter.

表 1 SIT (Tokin:TM502D) の最大定格

Table 1. Maximum rated values of SIT(Tokin : TM502D).

\begin{tabular}{ll}
\hline Gate-Drain Voltage & $450 \mathrm{~V}$ \\
Drain Current & $30 \mathrm{~A}$ \\
Gate Current & $0.1 \mathrm{~A}$ \\
Drain Loss & $400 \mathrm{~W}$ \\
Turn-on Time & $\sim 50 \mathrm{~ns}$ \\
Turn-off Time & $\sim 50 \mathrm{~ns}$ \\
\hline
\end{tabular}

表 2 SIT 高周波インバータ電源の主要性能 Table 2. Typical rated values of SIT inverter.

\begin{tabular}{ll}
\hline Input DC Voltage & $400 \mathrm{~V}$ \\
Input DC Current & $80 \mathrm{~A}$ \\
Output Power & $20 \mathrm{~kW}$ \\
Output Frequency & $0.2 \sim 2 \mathrm{MHz}$ \\
\hline
\end{tabular}


いた誘導コイルはコイル内径約 $80 \mathrm{~mm}$, 全長約 $200 \mathrm{~mm}$ で， コイル導体として $1 / 4$ インチ径の銅管を7 ターン巻いたも のを使用している。放電管は外径 $76 \mathrm{~mm}$, 肉厚 $3 \mathrm{~mm}$ の 1 重パイレックスガラス管を使用している。今回の実験で は, 高周波誘導熱プラズマの初期点火から熱プラズマへの 成長過程の解明に重点を置いていることから, 熱プラズマ の生成時間は最大でも数秒程度で, 誘導コイルとパイレッ クスガラス管は自然空冷のみで実験を行った。動作ガスで あるアルゴンは, 上部フランジに設置された 2 種類の導入 口（旋回流用と軸流用兴れ光れ 6 ケ所）から放電管内に導 入される。また, 兴の圧力および流量は, 弚れ光れ 20 $30 \mathrm{kPa}$ およ゙ $20 l / \mathrm{min}$ の領域に固定した。初期放電の立ち 上げを容易にするために，図 2 に示すように上部フランジ 中央に取り付けられたスパークプラグによる初期電子の供 給を行っている。これにより初期放電開始に必要なコイル 電流が約半分に低下し, 誘導プラズマの点火に必要な高周 波電力を大幅に低減している ${ }^{(11)}$ 。

誘導コイル負荷回路は, タップ切り替え方式のインピー
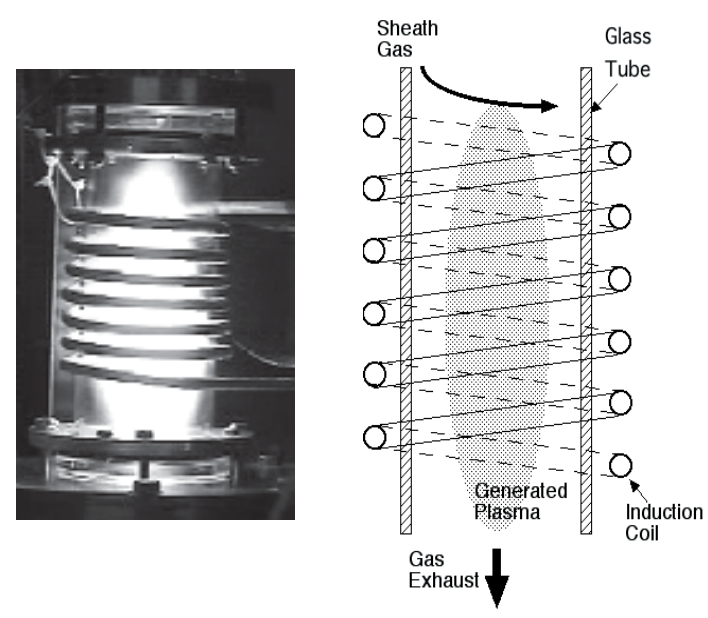

図 2 定常時のプラズマトーチ画像と誘導コイル形状

Fig. 2. Picture of the plasma torch and induction coil structure.

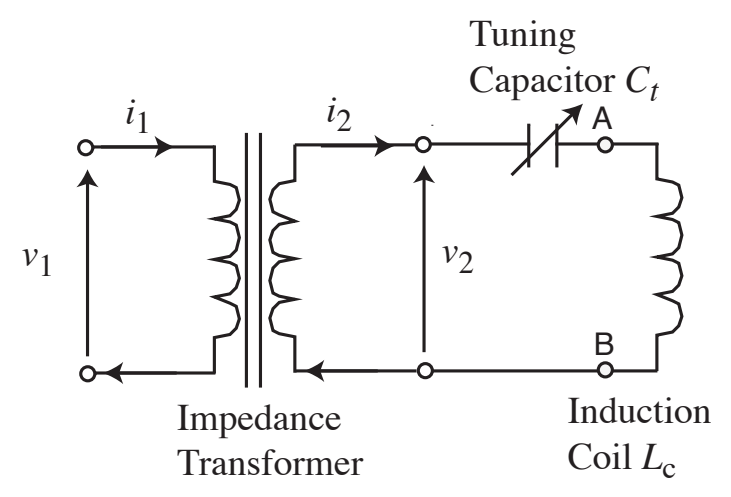

図 3 誘導コイル負荷回路

Fig. 3. Induction coil circuit.
ダンス変換用フェライトコアトランス (巻き数比 $a=1 / 4$ 1/1) とトランス 2 次側回路の直列共振回路を形成する 7 ターンの誘導コイルとバンク可変式のコンデンサ (Celem: モデル CP30/75 ) により構成されている。インバータ駆動 周波数は, 無負荷時において誘導コイル電流が最大値を取 るように, 図 3 の負荷回路におけるトランス入力電圧 $v_{1}$ と電流 $i_{1}$ が同相 (直列共振状態) となるように設定して いる。無負荷時において駆動周波数が $1 \mathrm{MHz}$ の時, 誘導 コイルインダクタンス $L_{\mathrm{c}}$ およびトランス 2 次側換算回路

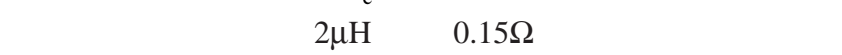
験では, 高周波電流通電時の誘導コイルを含めた高周波線 路の温度上昇による回路抵抗の増加は, 測定のばらつき( 10\%)内にとどまっていることから無視できるものとした。

〈2·2〉 誘導コイル負荷インピーダンスの動的変化の評 価誘導コイル負荷インピーダンスは, 誘導コイルに流 れる高周波電流により誘起される高周波電磁界と, 生成さ れるプラズマとの相互作用として, 兴の抵抗成分はプラズ マへの電力吸収の寄与を, リアクタンス成分は容量的ある いは誘導的な結合の寄与を反映したものとなる。誘導コイ ル端子間電圧とコイル電流の直接測定からコイル負荷イン ピーダンスを求める場合, 位相測定誤差がコイル負荷抵抗 の評価に大きな誤差をもたらす。今回の実験では, 図 3 に 示す誘導コイル負荷回路のインピーダンス変換トランス 1 次側電圧 (インバータ出力電圧 $v_{1}$ に相当) と電流 (インバー タ出力電流 $i_{1}$ に相当) の測定から, 以下に示す方法によ り直列共振用コンデンサおよびインピーダンス変換トラン スを含んだトランス 1 次側換算インピーダンス (インバー 夕負荷インピーダンスに相当) の時間変化を評価した。

インバータの瞬時電力は, インバータ出力電圧 $v_{1}(t)$ と 電流 $i_{1}(t)$ より, $p_{1}(t)=v_{1}(t) \times i_{1}(t)$ で与えられる。過渡的負

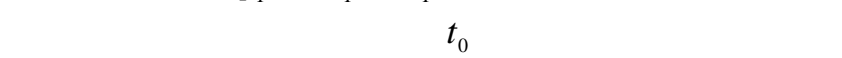
電流の実効値 $V_{1}\left(t_{0}\right), I_{1}\left(t_{0}\right)$, 有効電力 $P_{e f f}\left(t_{0}\right)$ および皮相電 力 $P_{a p p}\left(t_{0}\right)$ を产れ光れ，

$$
\begin{aligned}
& V_{1}\left(t_{0}\right)=\sqrt{\frac{1}{T} \int_{t_{0}-(T / 2)}^{t_{0}+(T / 2)} v_{1}^{2}(t) d t} \\
& I_{1}\left(t_{0}\right)=\sqrt{\frac{1}{T} \int_{t_{0}-(T / 2)}^{t_{0}+(T / 2)} i_{1}^{2}(t) d t} \\
& P_{\text {eff }}\left(t_{0}\right)=\frac{1}{T} \int_{t_{0}-(T / 2)}^{t_{0}+(T / 2)} v_{1}(t) \times i_{1}(t) d t \\
& P_{a p p}\left(t_{0}\right)=V_{1}\left(t_{0}\right) \times I_{1}\left(t_{0}\right)
\end{aligned}
$$

で定義する。図 3 に示す誘導コイル負荷回路のトランス 1 次側から見た負荷インピーダンスを $Z_{1}=R_{1}+j X_{1}$ とすると， 光れ光れ， 


$$
\left|Z_{1}\left(t_{0}\right)\right|=V_{1}\left(t_{0}\right) / I_{1}\left(t_{0}\right)
$$

$$
\begin{aligned}
& R_{1}\left(t_{0}\right)=P_{\text {eff }}\left(t_{0}\right) / I_{1}^{2}\left(t_{0}\right) \cdots \\
& \left|X_{1}\left(t_{0}\right)\right|=\sqrt{1-\xi^{2}}\left|Z_{1}\left(t_{0}\right)\right|
\end{aligned}
$$

で与えられる。ここで， $\xi$ は負荷回路の力率で， $\xi$ $=P_{e f f}\left(t_{0}\right) / P_{a p p}\left(t_{0}\right)$ で与えられる。2 次側インピーダンスは 1 次電流と 2 次電流との振幅比で評価したインピーダンス 変換卜ランスの巻き数比 $a=i_{1} / i_{2}$ を用いて, $Z_{2}=a^{2} Z_{1}$ として 求め, 誘導コイルのインダクタンス $L$ は, 既知である共 振用コンデンサーの容量 $C_{\mathrm{t}}$ を用いて, $\omega L=a^{2} X_{1}+1 / \omega C_{\mathrm{t}}$ よ り求めた。ここで評価される誘導コイルインダクタンスは, インピーダンス変換トランスの漏れインダクタンスや回 路インダクタンスを含んでいることに注意しておく。以後， 図 3 に示す誘導コイル負荷回路のトランス 1 次側から見た 負荷インピーダンスを 1 次側負荷インピーダンス $Z_{1}$, 誘 導コイル負荷インピーダンスを $Z_{\mathrm{L}}$ と区別して用いる。

\section{3. 実験結果とその検討}

〈3. 1〉可視高速カメラによる初期点火から誘導放電プラ ズマへの発展過程の観測 可視高速カメラにより観測し たアルゴン誘導熱プラズマ生成初期段階の代表的なプラズ マ画像の時間変化を図 4 , 图 5 に示す。图 4 の画像は, 1 台の高速カメラを用いて，光れ艺れ誘導熱プラズマトーチ 横 (図 2 の写真と同じ方向) からとトーチ軸方向から別々 の放電を撮影したものである。今回の実験では, 多数回の 放電により観測される画像の定性的な振る舞いや次節に示 すインバータ各部電圧と電流波形変化の再現性は確認して いる。图 4 の初期放電写真に見られるようにトーチ上部 フランジに取り付けられた点火プラグの放電ギャップから 放出される電子群からストリーマ上の放電が放電管軸方向 のコイル領域に延び，さらに多くのストリーマ状放電に進 展している樣子がわかる。放電管内面のコイル近傍でス卜 リーマ状放電が成長するのは，コイル導体間に発生する強 い近接静電場によるものと考えられる。これら放電管軸方 向のストリーマ状放電が多数発生し, 兴の後 $0.5 \sim 1 \mathrm{~ms}$ の 時間を経て周方向の誘導電界による誘導電流が放電管内周 辺部にリング状に誘起されている。この周方向の誘導電流 によりプラズマはジュール加熱され，放電管内部全体にわ たる誘導放電プラズマが形成されるまで成長している(12)。 このようなストリーマ状の静電放電から誘導放電への移行 と誘導熱プラズマへの成長は数 $\mathrm{ms} \sim 10 \mathrm{~ms}$ の時間スケー ルで起こり, 兴の後，図 2 に示すような安定な誘導熱プラ ズマが維持されている。

図 5 に見られるようにリング状誘導放電プラズマが成長 する過程で，リング状プラズマはジュール加熱による成長 と同時に放電管軸方向の振動磁界 $B_{z}$ と周方向に駆動され る誘導電流 $J_{\theta}$ による径方向内向きのローレンツカ $J_{\theta} \times B_{z}$

\section{Side View}
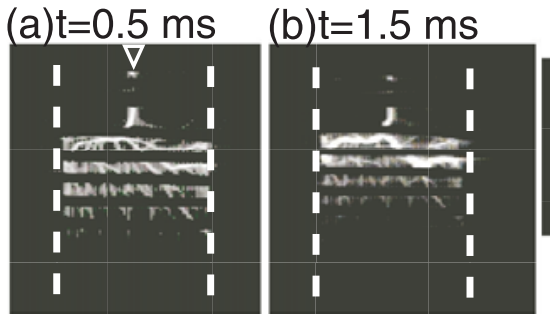

(c) $\mathrm{t}=2.5 \mathrm{~ms}$

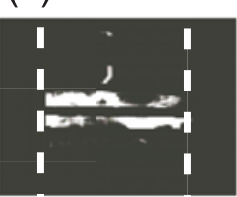

Top View
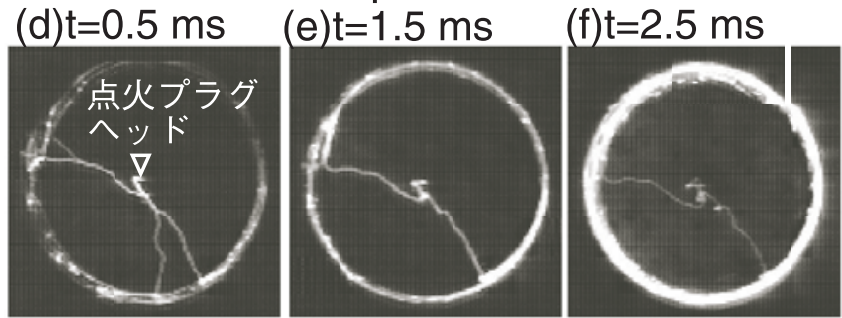

图4立ち上がり初期の放電画像，放電開始時刻を $t=0$ として時刻を表示している〔図中の破線はガラス 放電管壁の位置を示す。アルゴンガス圧力・流量 $30 \mathrm{kPa} \cdot 20 l / \mathrm{min}$ ，コイル電流周波数 : $1130 \mathrm{kHz}$ ， フレーム速度 : (a) 〜 (c): 4500fps，

$$
\text { (d) (f): 13500fps ] }
$$

Fig. 4. Pictures of initial startup discharges〔Dotted lines in the figure show the position of the glass tube wall. Time shown in the figure is counted from the discharge starting time. Argon gas pressure and flow rate are $30 \mathrm{kPa}$ and 20 $l / \mathrm{min}$, respectiv ely. The coil driving frequency is $1130 \mathrm{kHz}$. Camera frame rate is 4500fps in (a) - (c) and $13500 \mathrm{fps}$ in (d) (f)].

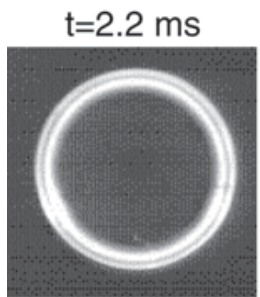

$\mathrm{t}=5.2 \mathrm{~ms}$

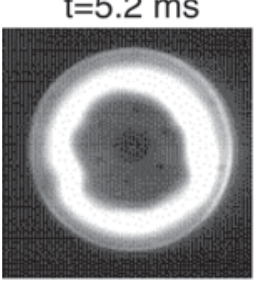

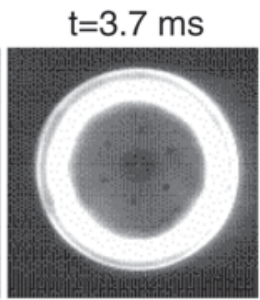

$\mathrm{t}=7.4 \mathrm{~ms}$

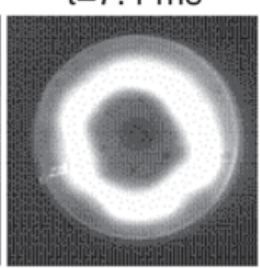

$\mathrm{t}=4.4 \mathrm{~ms}$

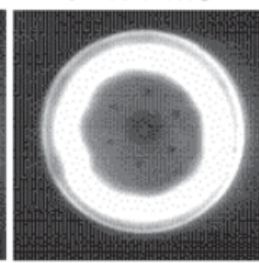

$\mathrm{t}=10 \mathrm{~ms}$

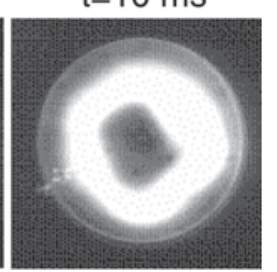

図 5 リング状誘導放電への移行後の時間発展の樣子 Fig. 5. Development of the ring-shaped inductive plasmas after E-H transition.

により放電管中心方向に収縮していく(13)(14)。最終的には， プラズマに対して内向きに働くローレンツカとプラズマ圧 カによる外向きの力とがバランスしながら熱プラズマへと 成長しているのものと考えられる。このような過渡応答を 経て , プラズマは自発的に放電管内壁との熱的接触を低減 
する方向に生成・維持される。

〈3. 2〉 初期点火から誘導放電プラズマへの発展過程に おけるインバー夕電源の振る舞い 図 4 , 図 5 に示され るような初期静電放電の開始から誘導放電への成長過程 は, 誘導コイルとプラズマとの電磁気的な結合特性やイン バータ電源の回路特性, 制御特性等を介して, 誘導コイル 電流を駆動しているインバータ電源の出力電圧・電流波形 の過渡変化として現れることとなる。図 6 に代表的なアル ゴンプラズマ生成時におけるインバータ各部の電流・電圧 波形と光れらより計算された直流および高周波電力変化を 示す。放電初期の放電管内壁付近での静電放電開始から誘 導放電への移行と成長期間 $(t=4 \sim 10 \mathrm{~ms})$ の間にインバー 夕出力電圧と電流および高周波電力が大きく変動し, 放電 管内部全体に誘導熱プラズマが形成された後 $(t \sim 20 \mathrm{~ms})$, 熱プラズマとガラス放電管や金属フランジとの熱的な相互 作用により緩やかな時間スケールで変化し，安定な誘導熱 プラズマの形成に至っている。初期ストリーマ状静電放電 からリング状誘導放電への移行と光れに続く熱プラズマへ の成長という放電特性が急激な変化と光れに伴うインバー 夕高周波電源の応答特性を調べるために, プラズマ点火 前後を拡大したものを図 7 に示す。放電開始 $(t \sim 4.5 \mathrm{~ms})$ から $t \sim 6 \mathrm{~ms}$ までのストリーマ状静電放電時は, インバー 夕出力電圧と電流に大きな変化はなく, 1 次側負荷イン ピーダンス $Z_{1}$ の変化も小さいことがわかる。また 、図 7 (c) に示されているように, 直流入力電力とインバータ有効電 力はほぼ等しく，インバータ直流一交流変換効率 (以下， インバータ効率と記す) (約 $90 \%$ となっている。ここで， 特徵的なことは, 無負荷時に $X_{1}=0$ の直列共振状態にあっ た 1 次側負荷インピーダンスがわずかではあるが正のリア クタンス成分を持ち, インバータ負荷は誘導性負荷として 働いている。产の後, 図 4 , 図 5 の画像に見られるような リング状誘導放電への移行 $(t \sim 6 \mathrm{~ms})$ とともにインバー 夕出力電圧の急上昇と電流の急低下, 直流入力電力の急上 昇とインバータ効率の低下が見られる。一方，1次側負荷 インピーダンス $Z_{1}$ には, 抵抗成分 $R_{1}$ の急上昇とリアクタ ンス成分 $X_{1}$ の負側への大きな变化が見られている。

このような負荷インピーダンスの変化は, 図 8 に示す誘 導コイルの等価回路を考えると分かりやすい。誘導コイル 端に発生する電圧降下 $V_{\mathrm{c}}=\left(R_{\mathrm{c}}+j \omega L_{\mathrm{c}}\right) i_{2}$ により, 誘導コイル 導体間に高周波静電界が発生する。図 7 に示す放電例では， 静電放電時に発生する誘導コイル端子電圧は, $V_{\mathrm{c}}=2.5 \sim$ $3 \mathrm{kV}$ である。この高周波静電界により生成・維持される静 電放電は, ガラス放電管外部に巻かれたコイル導体からガ ラス誘電体を介して放電電流が流れる一種のバリアー放電 形式をとることから炎の電流值は大気中および誘電体を流 れる変位電流で制限され, 投入電力も少ない。このような 静電放電時の等価回路として, 誘導コイルと並列にコンデ ンサーと抵抗が接続された形となる。この時, 誘導コイル リアクタンスは ,
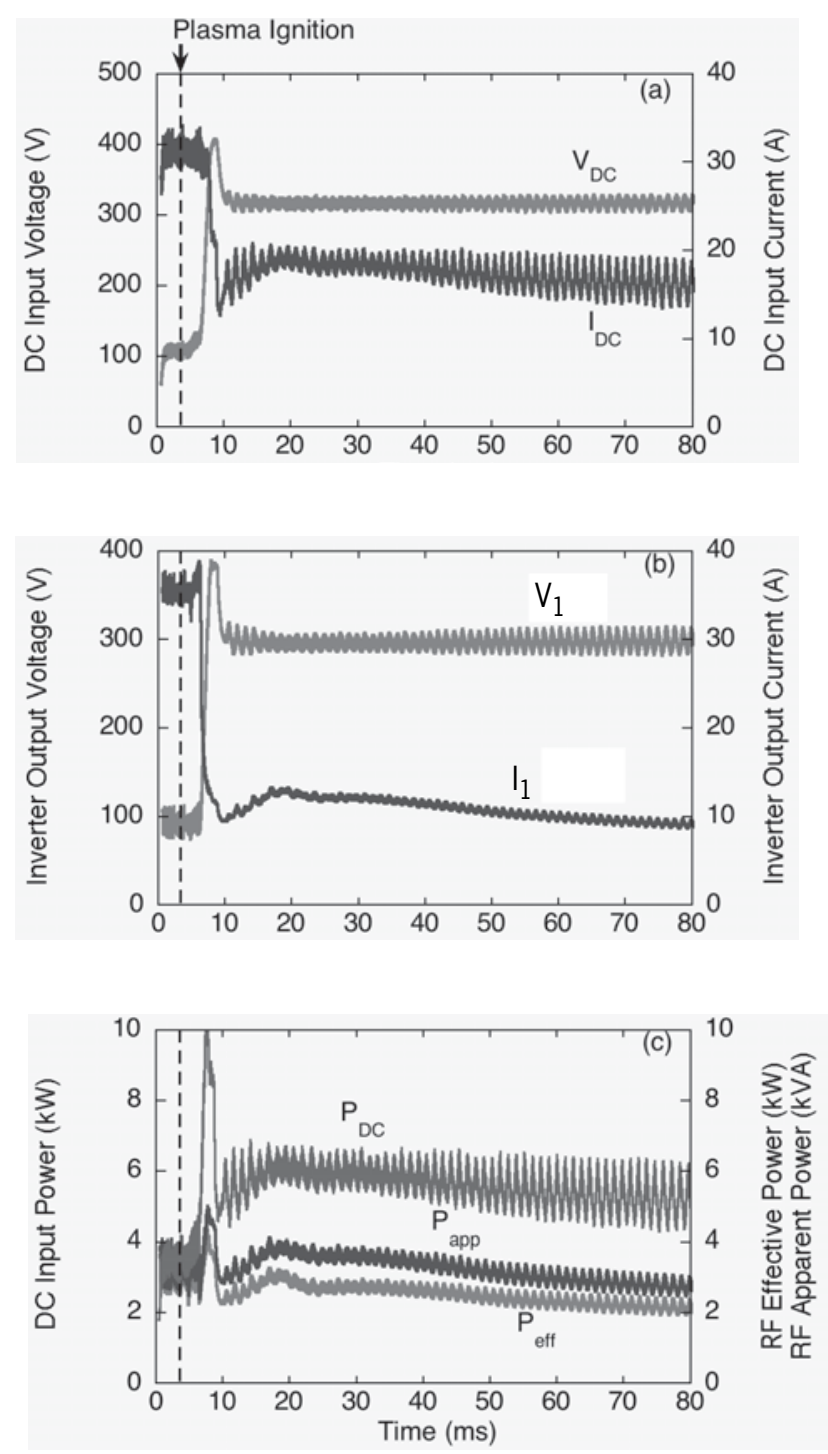

図6 高周波誘導熱プラズマ初期放電開始から定常誘導熱 プラズマ生成に至までの直流入力電圧, 電流 (a), イン バータ出力電圧 $V_{1}$, 電流 $I_{1}(\mathrm{~b})$, 直流入力電力 $P_{\mathrm{dc}}$ と高周波皮相 $P_{\mathrm{app}}$, 有効電力 $P_{\mathrm{eff}}(\mathrm{c})$ 波形 (実験条件は図 4 と同じ)

Fig. 6. Typical waveforms of the DC input voltage $V_{\mathrm{dc}}$ and current $I_{\mathrm{dc}}(\mathrm{a})$, inverter output voltage $V_{1}$ and current $I_{1}(\mathrm{~b})$, DC input power, rf apparent $P_{\text {app }}$ and effective power $P_{\text {eff }}(\mathrm{c})$ when the $\mathrm{rf}$ induction thermal plasma is generated and sustained (Experimental conditions are same as those in Fig. 4).

$$
\operatorname{Im}\left[Z_{L}\right]=\frac{1-\omega^{2} L_{c} C_{p}^{e s}+\left(\omega C_{p}^{e s} R_{p}^{e s}\right)^{2}}{\left(1-\omega^{2} L_{c} C_{p}^{e s}\right)^{2}+\left(\omega C_{p}^{e s} R_{p}^{e s}\right)^{2}} \omega L_{c}
$$

で与えられる。 $\omega^{2} L_{\mathrm{c}} C_{\mathrm{p}} \mathrm{es}<1$ のとき，(8) 式で与えられ誘導 コイルリアクタンスは無負荷時の值 $\omega L_{\mathrm{c}}$ より大きくなる。 その結果として, 実効的な誘導コイルインダクタンスが増 加し, 1 次側負荷インピーダンス $Z_{1}$ としては誘導性負荷 側に変化することになる。図 8 の等価回路を用いて, 図 7 に示す代表的な静電放電時におけるプラズマ負荷抵抗 $R_{\mathrm{p}}$ es 

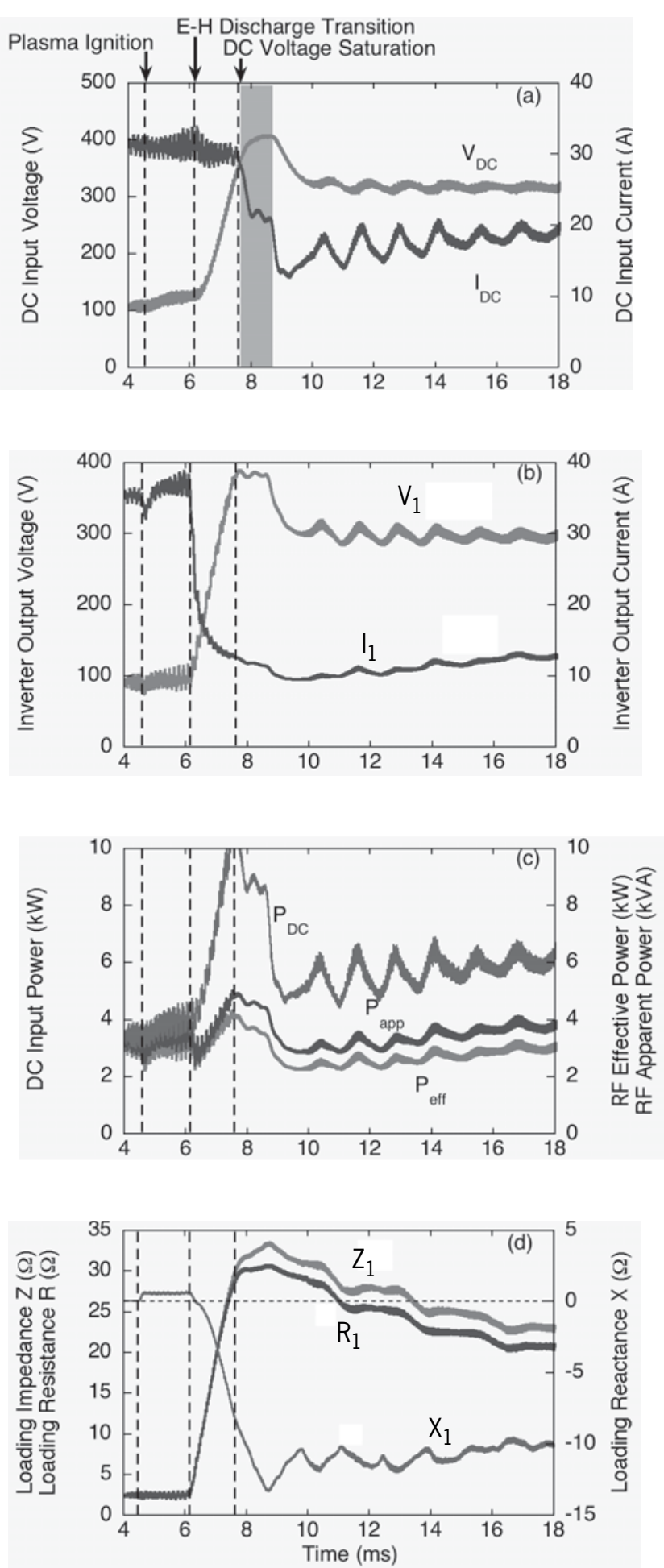

図7高周波誘導熱プラズマ点火前後の直流入力電圧， 電流 (a)，インバー夕出力電圧, 電流(b), 直流入力

電力と高周波皮相 $P_{\mathrm{app}}$, 有効電力 $P_{\mathrm{eff}}(\mathrm{c})$ と 1 次

側負荷インピーダンスの絶対值 $\left|Z_{1}\right|$ ，負荷抵抗

$R_{1}$ と負荷リアクタンス $X_{1}(\mathrm{~d})$ の時間変化

Fig.7. Time behavior of the DC input voltage and current (a), inverter output voltage and current (b), DC input power, rf apparent $P_{\text {app }}$ and effective power $P_{\text {eff }}$ (c), and loading impedance $Z_{1}$, loading resistance $R_{1}$ and reactance $X_{1}$ (d) in the initial startup phase of induction thermal plasmas.

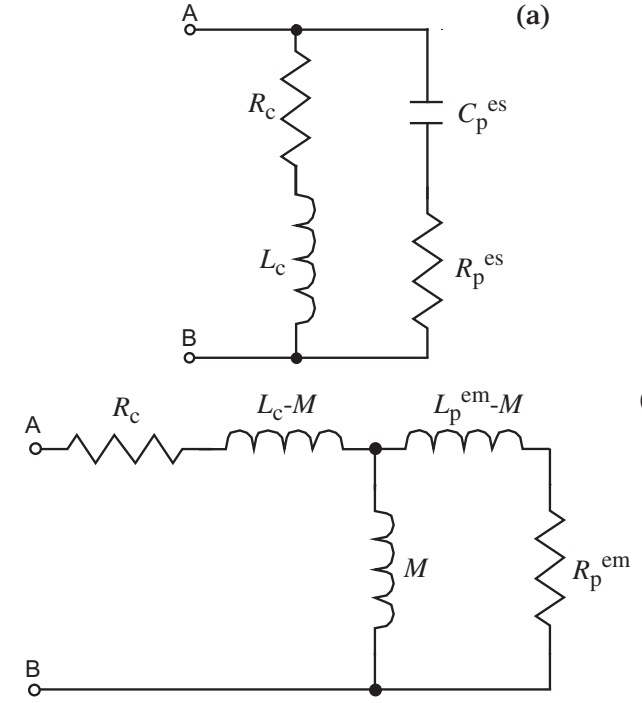

(b)

図8 静電放電時 (a) と誘導放電時 (b) における誘導 コイル回路の等価回路 (ここで $L_{\mathrm{c}}, R_{\mathrm{c}}$ は，光れ光れ， 無負荷時における誘導コイルのインダクタンスと 抵抗， $C_{\mathrm{p}}$ es,$R_{\mathrm{p}} \mathrm{es}^{\mathrm{es}}$ は兴れ光れ静電放電時の等価的

容量と抵抗を表す。また $, M, L_{\mathrm{p}}^{\mathrm{em}}, R_{\mathrm{p}}^{\mathrm{em}}$ は，

兴れ光れ誘導放電時の相互インダクタンス，

プラズマの自己インダクタンスと抵抗を表す)

Fig. 8. Equivalent circuits of induction coil circuit in the electrostatic (a) and electromagnetic (b) discharges (Here, $L_{\mathrm{c}}$ and $R_{\mathrm{c}}$ are the inductance and resistance of the induction coil without plasma loading, respectively. $C_{\mathrm{p}}$ es and $R_{\mathrm{p}}{ }^{\text {es }}$ are the effective capacitance and resistance of the electrostatic discharge respectively. And $M, \mathrm{~L}_{\mathrm{p}}{ }^{\mathrm{em}}$ and $R_{\mathrm{p}}{ }^{\mathrm{em}}$ are the mutual inductance, self inductance and resistance of the inductive discharge plasma).

および静電容量 $C_{\mathrm{p}}^{\mathrm{es}}$ を評価したところ, $R_{\mathrm{p}}{ }^{\mathrm{es}}=3 \sim 8 \mathrm{k} \Omega$, $C_{\mathrm{p}}^{\mathrm{es}}=20 \sim 40 \mathrm{pF}$ であった。

一方, リング状放電以降の誘導放電時には, プラズマは 誘導コイルとの間に相互インダクタンス $M$ を持つ導電性 媒体として働き, 誘導コイルの等価回路は図 8 (b) で与え られる。光のインピーダンスは，

$$
\begin{aligned}
Z_{L}= & \left(R_{C}+\frac{\omega^{2} M^{2} R_{p}^{e m}}{\left(R_{p}^{e m}\right)^{2}+\omega^{2}\left(L_{p}^{e m}\right)^{2}}\right) \\
& +j \omega\left(L_{C}-\frac{\omega^{2} M^{2} L_{p}^{e m}}{\left(R_{p}^{e m}\right)^{2}+\omega^{2}\left(L_{p}^{e m}\right)^{2}}\right)
\end{aligned}
$$

で与えられる。誘導放電の場合，実効的コイルインダクタ ンスは ,

$$
\frac{\omega^{2} M^{2} L_{p}^{e m}}{\left(R_{p}^{e m}\right)^{2}+\omega^{2}\left(L_{p}^{e m}\right)^{2}}
$$

だけ減少し, LCR 直列共振回路で構成されるインバータ 負荷インピーダンス $Z_{1}$ としては容量性側に変化すること になる。また, 誘導コイルの負荷抵抗は, 無負荷時 $\left(R_{\mathrm{p}}{ }^{\mathrm{em}}=\right.$ $\infty, M=L_{\mathrm{p}}{ }^{\mathrm{em}}=0$ に対応) の $R_{\mathrm{c}}$ から 


$$
\frac{\omega^{2} M^{2} R_{p}^{e m}}{\left(R_{p}^{e m}\right)^{2}+\omega^{2}\left(L_{p}^{e m}\right)^{2}}
$$

だけ増加することになる。(11) 式で与えられる負荷抵抗の 増加分は, 誘導プラズマが持つ抵抗 $R_{\mathrm{p}}^{\mathrm{em}}$, 誘導プラズマ 中に流れる高周波電流分布により決定される誘導プラズマ のインダクタンス $L_{\mathrm{p}}^{\mathrm{em}}$ および誘導コイル - プラズマ間の 相互インダクタンス $M$ に依存することから，生成される 誘導プラズマの密度や温度および弚れらの分布や中性ガス 圧力等により大きく変化すると考えられる。実際の実験で は, 図 6 , 図 7 に示されるように熱プラズマ成長時 $(t=6$ 〜 8ms）には,プラズマ加熱により電子密度および温度が 上昇し, 弚れによりプラズマ加熱電力が上昇し,さらに電 子密度および温度が上昇するといった正帰還作用によりコ イル負荷抵抗が急上昇していると考えられる。

次に，高周波誘導熱プラズマ生成時における高周波イン バータの過渡応答特性について検討する。図 6 , 図 7 に示 した例では, インバータ出力電流を約 $35 \mathrm{~A}$ に制御してお り, 負荷インピーダンス $Z_{1}$ が小さい静電放電時 $(t=4.5 \mathrm{~ms}$ 〜 6ms) にはほぼ一定電流に保たれている。弚の後, 誘導 放電への移行とともに負荷インピーダンス $Z_{1}$ が急激に上 昇し，定電流特性を維持するようにインバータ出力電圧が 上昇する。しかしながら，インバータ出力電圧が直流部設 定電圧で規定される值に達すると，もはや关れ以上のイン ピーダンス上昇に対して定電流特性を維持できなくなり， インバータ出力電流は低下することになる。図 6 , 図 7 の 例では, 直流出力電圧〜 320V で制限をかけていることか ら, $t \sim 7.5 \mathrm{~ms}$ 付近からの過渡応答を経て DC 電圧, インバー タ出力電圧ともにほぼ一定電圧で推移している。

これに対して，インバータ出力の時間変化を見ると，イ ンバータ出力電圧はほぼ直流電圧変化に対応して変化する が, 出力電流の低下が静電放電から誘導放電への移行とほ ぼ同時に起こっていることがわかる。これは，DC-DC コ ンバータの持つ応答時間が約 $0.4 \mathrm{~ms}$ と遅いため, 負荷イン ピーダンスの急激な変化に追従できていないことと，イン バータ負荷インピーダンスが誘導放電への移行により容量 性負荷になり，インバータ素子のスイッチング損失の増大 することによるものと考えられる。一般的に電圧共振型イ ンバータでは, スイッチング損失低減のためにスイッチン グ素子に印加される電圧がゼロの時にスイッチ動作させる ゼロ電圧スイッチング (ZVS) を行っている ${ }^{(15)}$ 。今回の 実験のように, 負荷リアクタンスの変化により共振状態 から外れた場合には, ゼロ電圧スイッチング動作が行えず に，インバータのスイッチング損失か増えることになる。

特に, 容量性負荷の場合, オフ状態のSIT 素子に高い電圧 が印加されている時にオフからオン状態に変化するために スイッチング損失か増大する。このようなインバータ電源 のゼロ電圧スイッチングからの逸脱によるスイッチング損 失の増大が, 実験で観測されたインバータ出力電流やイン バー夕効率の低下を招いているものと考えられる。今回の
実験で観測されたインバータスイッチング損失の増大は， MOSFETやパワートランジスタを用いた大電力半導体イ ンバーター電源を誘導熱プラズマ発生装置に適用する場合 に共通する問題である。

〈3.3〉駆動周波数掃引による熱プラズマ生成効率改善 の試み＼cjkstart前節で述べたように誘導熱プラズマ生成時に， 数 $\mathrm{ms}$ の時間スケールでインバータ負荷が無負荷時の低抵 抗負荷から静電放電時の誘導性負荷, さらに誘導放電時の 容量性負荷に急変する。また，誘導熱プラズマへの成長に 合わせてコイル負荷抵抗も無負荷時の〜 $0.15 \Omega$ から 1 〜 $2 \Omega$ に急上昇する。これら一連の変化は，インバータ電源 に対して負荷インピーダンスの急激な増大とゼロ電圧ス イッチングからの逸脱を招き, 弚の結果, インバータ出力 電流の低下，インバータ効率の低下やプラズマ吸収電力の 低下等が起こると考えられた。本節では, 駆動周波数帰還 制御による負荷共振状態の保持と高周波誘導熱プラズマ 生成効率の改善のために行った予備実験結果について述 ベる。

実験ではインバータ駆動周波数を熱プラズマ生成中に事 前に設定されたスタート周波数からストップ周波数まで掃 引し，インバータ負荷インピーダンスを共振状態の純抵抗 負荷を挟んで容量性から誘導性負荷まで変化させ，光の時 のインバータ出力特性を測定した。周波数掃引したときの 代表的な波形を図 9 に示す。インバータ駆動周波数の初期 設定值を $1120 \mathrm{kHz}$ に設定してプラズマを点火し, 準定常 的な誘導熱プラズマが形成された後, $20 \mathrm{~ms}$ 間で $1120 \mathrm{kHz}$ から $1250 \mathrm{kHz}$ まで掃引している。図 9 (a) は,インバーター 駆動周波数とインバータ電圧と電流の実測波形から瞬時負 荷インピーダンスを求め, 兴の值から評価した負荷の共 振周波数である。 $t=40 \mathrm{~ms}$ の掃引開始前は, 共振周波数よ り駆動周波数の方が低く，図 3 に示す LCR 直列回路から 構成される 1 次側負荷インピーダンス $Z_{1}$ は容量性であり， 図 9 (d) に示されるように,インバータ効率 $\left(P_{\mathrm{app}} / P_{\mathrm{dc}}\right)$, イ ンバータ出力 $\left(P_{\text {eff }}\right)$ および負荷力率 $\left(P_{\text {eff }} / P_{\text {app }}\right)$ がともに低い 状態である。掃引前の負荷の共振周波数は約 $1170 \mathrm{kHz}$ で

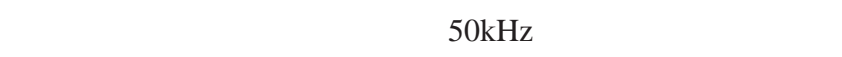
ら駆動周波数を上げていくと, 図 9 (d) に見られるように インバーター出力電力の上昇が見られるのと同時に負荷共 振周波数も上昇している。これは, 駆動周波数を負荷共振 周波数に近づけることによりプラズマへの吸収電力が増 加し, 生成されているプラズマの密度および温度か増加す る。光の結果，(10) 式においてプラズマ抵抗 $R_{\mathrm{p}}^{\mathrm{em}}$ が低下し， 同時に誘導コイルとプラズマ間の相互インダクタンス $M$ が上昇し, 結果として誘導コイルインピーダンスをより容 量性負荷の方向にしたものと考えられる。プラズマ温度お よび密度の動的な变化は, 図 9 (e) に示される1次側負荷 抵抗 $R_{1}$ の上昇としても現れている。このような状況下で 駆動周波数をさらに上げていくと図 9 (e) に見られるよう に 1 次側負荷リアクタンス $X_{1} \sim 0 \Omega$ の共振状態を得るこ とができる。インバータ出力電力も図 9 (d) に示すように 

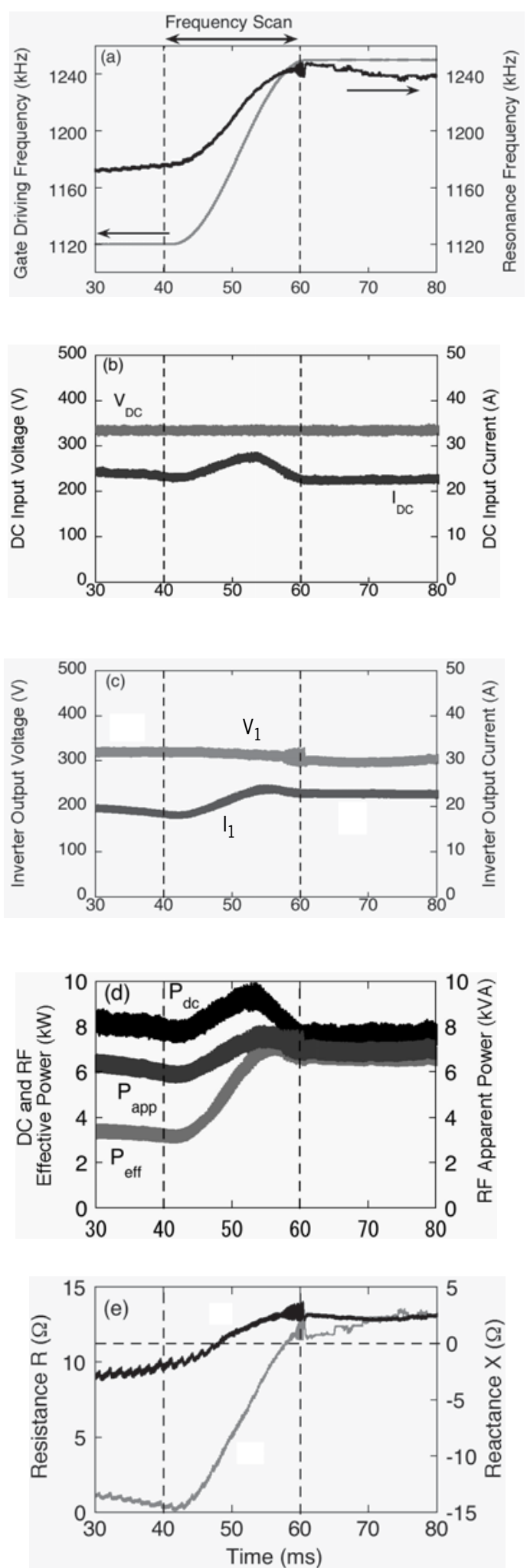

図9インバータ駆動周波数を掃引した時の駆動周波数 と誘導コイル回路の共振周波数 (a), 直流電圧 , 電流 (b)，インバータ電圧, 電流 (c), 直流電力と インバータ出力電力 $(\mathrm{d})$ および 1 次側負荷 インピーダンス (e) の時間変化

Fig. 9. Time traces of the inverter driving frequency and the resonance frequency (a), DC input voltage and current (b), inverter output voltage and current (c), dc and rf power (d) and loading inpedance (e) when the inverter driving frequency is varied as shown in Fig. 9 (a).
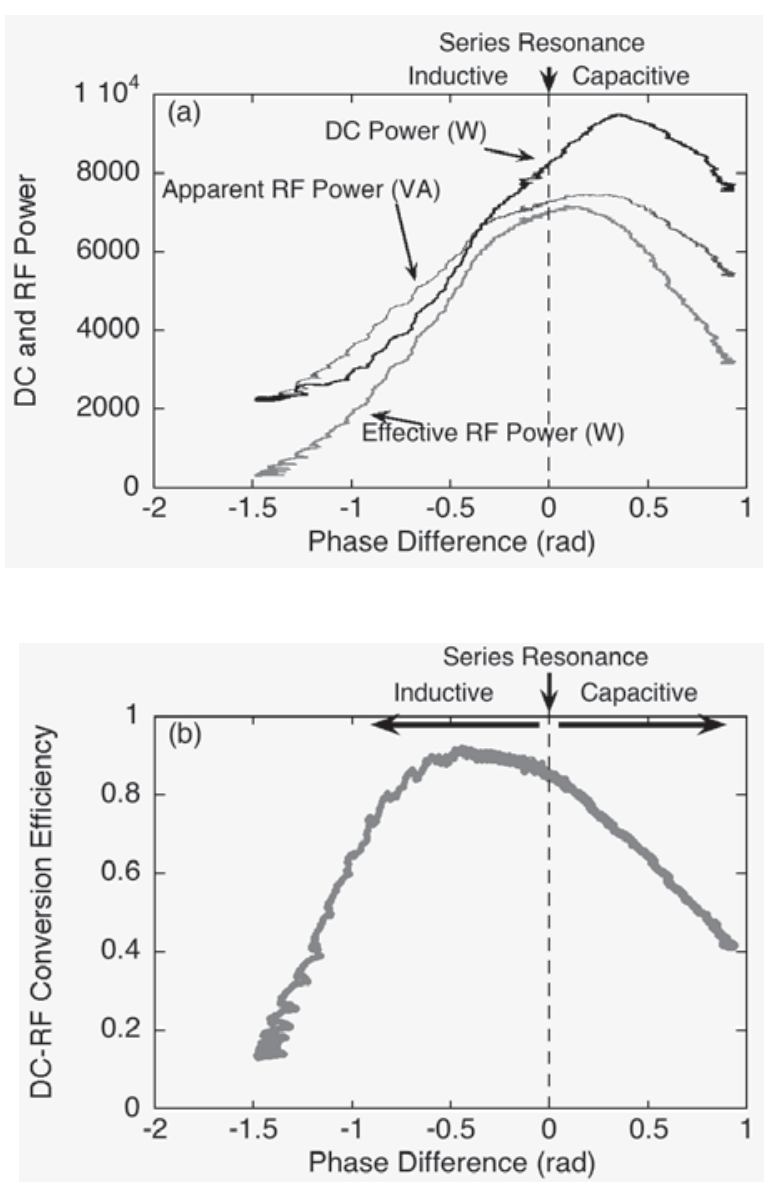

図 10 周波数掃引を行ったときのインバータ出力電圧一 電流位相差に対する直流およびインバータ出力 (a) とインバータ効率 (b) の変化

Fig. 10. Phase dependence of the DC input power and inverter output power (a) and the inverter efficiency (b) when the inverter driving frequency is swept.

$3.5 \mathrm{~kW}$ から $7 \mathrm{~kW}$ まで上昇し，インバータ効率も約 $85 \%$ ま で回復している。図 9 に示すようなインバータ駆動周波数 を掃引することで得られたインバータ出力電力およびイン バータ効率の負荷力率依存性を图 10 に示す。負荷力率が 最大 (インバータ出力電圧一電流位相差が最小) になるよ うに周波数同調を取ることで, インバータ出力を最大点付 近に維持でき，かつインバータ効率も最大付近に保つこと が出来ることがわかる。また , 共振状態からのずれに対し て, 容量性負荷側の方か誘導性負荷に比ベてインバータ効 率の低下が大きく，周波数を固定して誘導熱プラズマを生 成した場合，誘導熱プラズマ形成時（容量性負荷時）にお いてインバータ効率が大きく低下したことを定性的に説明 できるものである。

今回の実験において, 電圧共振型インバータ動作時にお ける周波数制御が, 誘導コイルと生成されるプラズマとの 電磁気的相互作用，およびプラズマの動的自己形成過程を 通してインバーターの運転特性に強く影響することか確認 された。また，金属材料・部品の誘導加熱装置等に用いら れている位相ロックループ (PLL) を用いた周波数帰還制御 
を用いて, 高い負荷力率およびインバータ効率を保ちなが ら, 誘導熱プラズマ生成の高効率化を行うことが重要であ ることが示された。

\section{4.まとめ}

$\mathrm{MHz}$ 帯の高周波インバータを用いた高周波誘導熱プラ ズマ生成時に観測されるストリーマ状の高周波静電放電の 発生から誘導放電への遷移と光の後の誘導熱プラズマへの 動的発展過程, および光れに伴うインバータ電源の動的応 答特性を高速カメラによる画像観測と誘導コイル負荷特性 から明らかにした。

誘導コイルを用いた高周波誘導熱プラズマの初期生成過 程は, プラズマ点火時にガラス放電管内壁に沿って誘導コ イルの軸方向に発生するストリーマ状静電放電と光れに続 く放電管周方向のリング状誘導放電の形成とジュール加熱 による熱プラズマへの成長段階に分けられることが, 高速 カメラ画像および高周波電力測定に基づく誘導コイル負荷 インピーダンス測定により明らかになった。これら一連の プラズマ生成, 成長過程と誘導コイル負荷インピーダンス の動的変化は, 簡単な誘導コイルの等価回路モデルで説明 出来るものである。このような誘導熱プラズマの点火, 成 長過程や先の安定性はガス圧力の他に動作ガス種やガス導 入法にも強く依存すると考えられることから，旋回ガス流 とプラズマ回転特性やプラズマ回転のプラズマの生成・安 定性への寄与等について研究を進めていく必要がある。

誘導熱プラズマ生成時における誘導コイルとプラズマと の磁気結合により誘導コイルインダクタンスが減少する。 これによりインバータ負荷回路である LCR 直列共振回路 のインピーダンスは無負荷時の純抵抗負荷から容量性負荷 へと変化し, インバータ直流一交流変換効率とプラズマ加 熱電力の大きな低下を招いた。インバータ効率の大きな低 下は, 容量性負荷によるインバータスイッチング損失の増 大によるものである。初期的な周波数掃引実験により，初 期静電放電から誘導熱プラズマへ移行後に直列共振周波数 に周波数同調を取ることでプラズマ加熱電力を 2 倍ほど増 加でき, インバータ変換効率も〜 $85 \%$ と高い值が得られ ることが示された。

\section{謝 辞}

本研究を行うにあたり，SIT インバータの運転や動作解 析について貴重な助言を頂きました (株) 電気興業, 富里 哲夫氏に，誘導熱プラズマ装置に関する技術的な支援を頂 きました名古屋大学技術部，高木誠氏に感謝いたします。 また, 誘導熱プラズマの特性に関して多くの議論をしてい ただきました金沢大学自然科学研究科, 田中康規氏に感謝 いたします。

(平成 16 年 5 月 13 日受付, 平成 17 年 5 月 2 日再受付)
文献

(1) M. Amakawa, K. Adachi, and S. Yasui: "Fundamental Research of Thermal Plasma Treatment of Low Level Radioactive Solid Waste, Part II Influence of Waste Composition on Material Properties of Solidified Products", T. IEE Japan, Vol. 119-A, No. 3, pp. 357-364(1999-3) (in Japanese)

天川正士・足立和郎・安井晋示 : 「低レベル放射性杂隹固体廃棄物 のプラズマ溶射技術の基礎検討 兴の 2 溶融固化体の性状に 与える廃棄物組成の影響」, 電学論 A, 119, 3, pp. 357-364 (1999-3)

(2) K. Adachi and M. Amakawa: "Mechanism and Countermeasurements for Voltage Increase of Transfered Arc Plasma after Feeding Burnable Waste", T. IEE Japan, Vol. 119-A, No. 7, pp. $977-983$ (1999-7) (in Japanese)

足立和郎・天川正士 : 「移行型アークプラズマ加熱における可燃 性廃棄物投入時の電圧上昇の機構と対策」, 電学論 A, 119, 7, pp. 977-983 (1999-7)

(3) "Thermal Plasmas for Hazardous Waste Treatment", Proc. Int. School of Plasma Physics, Varenna, 1995, R. Benocci, G. Bonizzoni, and E. Sindoni, and Ed., World Scientific Publishing, Singapore (1996)

(4) H. Komaki, Y. Sugawara, and S. Konno: "The Development of Applications to Utilize the Characteristics of Radio-Frequency Thermal Plasmas", J. Plasma Fusion Res., Vol 76, No. 8, pp. 731-737 (2000) (in Japanese)

小牧 久・菅原吉則・今野茂生 :「高周波熱プラズマの特徵を生 かした用途開発」,プラズマ・核融合学誌, 76, No.8, pp. 731-737 (2000)

(5) M. Sakano and M. Tanaka: "The Effect of Frequency on Characteristics of Radio-Frequency Plasmas and the Application of the Plasma for Waste Treatment", J. Plasma Fusion Res., Vol 76, No. 8, pp. 748-753(2000) (in Japanese)

坂野美菜・田中元史:「高周波熱プラズマの周波数依存性 と廃棄物処理応用」, プラズマ・核融合学誌, 76, No.8, pp. 748-753(2000)

(6) T. Sakuta, Y. Tanaka, Y. Hashimoto, and M. Kouzuki: “ A Novel System of an Inductively Coupled Thermal Plasma with Pulse Amplitude Modulation of Electromagnetic Field", T. IEE Japan, Vol. 120-A, No. 11 , pp. 972-978 (2000-11) (in Japanese)

作田忠裕・田中康規・橋本吉史・香月 真 : 「高周波電磁界の $\mathrm{AM}$ 変調機能を有する高気圧誘導熱プラズマ方式の開発」, 電学 論 A, 120,11 , pp. 972-978 (2000-11)

(7) T. Ishigaki, Xiaobano Fan, T. Sakuta, T. Banjo, and Y. Shibuya: "Generation of Pulse-Modulated Induction Thermal Plasma at Atmospheric Pressure”, Appl. Phys. Lett., Vol. 71, pp. 3787-3789 (1997)

(8) H. Fujita, H. Akagi, and S. Shinihara: "A 2-MHz 6-kVA Voltage-Source Inverter Using Low-Profile MOSFET Modules for Low-Temperature Plasma Generators", IEEE Trans. Power Electronics, Vol. 14, No. 6, pp. 1014-1027 (1999)

(9) S. Watanabe, Y. Uesugi, S. Ohsawa, and S. Takamura: "Application of High Performance Inverter Circuit to Plasma Generation and Heating in Fusion Devices", Rev. Sci. Instrum., Vol. 69, pp. 355-357 (1998)

(10) T. Imai, H. Sawada, N. Hattori, Y. Uesugi, and S. Takamura: "Characteristic Performance of Radio-Frequency (RF) Plasma Heating Using Inverter RF Power Supplies”, T. IEE Japan, Vol. 120-A, No. 7, pp 768-774 (2000-7) (in Japanese)

今井貴博・澤田博之・服部德文・上杉喜彦・高村秀一: $「$ インバー 夕式高周波電源を用いたプラズマの加熱特性」, 電学論 A ,120, 7, pp. 768-774 (2000-7)

(11) Y. Uesugi, T. Adachi, K. Kondo, and S. Takamura: "Improved Ignition of a Radio-Frequency Thermal Plasma Using Repetitive Spark Discharges and its CHaracteristic Performance", T. IEE Japan, Vol. 122-A, No. 5, pp. 461-468 (2002-5) (in Japanese)

上杉喜彦・安達丈泰・近藤健二・高村秀一：「繰り返し火花放電 を用いた高周波誘導熱プラズマの初期点火の改善と炎の基礎特 性」, 電学論 A, 122, 5, pp. 461-468 (2002-5)

(12) M. A. Razzak, K. Kondo, Y. Uesugi, and N. Ohno, and S. Takamura: "Transition from Electrostatic to Electromagnetic Mode in a RadioFrequency Ar Inductively Coupled Plasma in Atmospheric Pressure", $J$. Appl. Phys., Vol. 95, pp. 427-433 (2004)

(13) T. Watanabe: "Physical and Chemical Processes in Radio Frequency Thermal Plasmas", J. Plasma Fusion Res., Vol. 72, No. 1, pp. 134-141 (1996) (in Japanese)

渡辺隆行 : 「2. 高周波誘導熱プラズマにおける物理・化学過程」, プラズマ・核融合学誌, 72, No.1 pp. 134-141 (1996)

(14) K. Kondo, M. A. Razzak, Y. Uesugi, and S. Takamura: "Electromagnetic 
Field Measurement in the Radio Frequency Inductively Coupled Plasma", The Papers of Technical Meeting on Plasma Science and Technology, IEE Japan, PST-02-45, pp. 13-18 (2002) (in Japanese) 近藤健二・M. A. Razzak ·上杉喜彦・高村秀一：「高周波誘導熱 プラズマの電磁場計測」, 電気学会プラズマ研資 , PST-02-45, pp. 13-18 (2002)

(15) 今井孝二 監修 : パワーエレクトロニクス, 第 II-2 章, R\&D プ ランニング (2002)
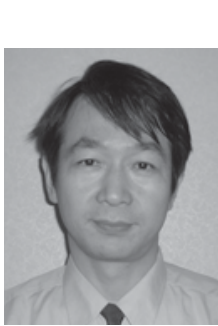

(正員) 1955 年 2 月 11 日生まれ。1982 年 3 月 名古屋大学大学院工学研究科電気・電子工学専 攻博士課程満了。同年 4 月日本原子力研究所入 所。1989 年 7 月名古屋大学工学部講師, 1993 年 同助教授。1996 年同大学理工科学総合研究セン タ一助教授, 2003 年 12 月金沢大学工学部教授, 2004 年 4 月金沢大学自然科学研究科教授, 現在 に至る。プラズマ・核融合科学と光の応用に関 する研究に従事。工学博士。プラズマ・核融合学会, 日本物理学会会員。

能司 洋 史 (学生員) 1981 年 1 月 12 日生まれ。2003 年東京

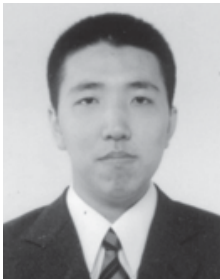
理科大学理工学部物理学科卒業。2003 年名古屋 大学大学院工学研究科エネルギー理工学専攻入 学, 現在に至る。

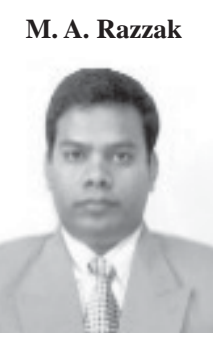

(学生員) M. Abdur Razzak received his BS degree in Electrical and Electronic Engineering from Rajshahi University of Engineering and Technology (former BIT Rajshahi), Bangladesh in 1995 and MS degree in Energy Engineering and Science from Nagoya University, Japan on March 2003. He is currently pursuing the $\mathrm{Ph}$. D. degree at the same university. He is a student member of IEEE, IEEE Nuclear and Plasma Sciences Society, Japan Society of Plasma Science and Nuclear Fusion Research, Institute of Electrical Engineers of Japan and Institute of Engineers on Electrical Discharges in Japan. His research interest includes high-power inverter power source, induction heating and high-pressure rf inductively coupled plasmas for plasma processing.

高 村 秀 一 (正員) 1943 年 7 月 3 日生まれ。1971 年 3 月名

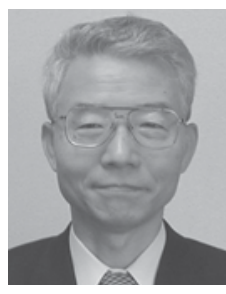
古屋大学大学院工学研究科電気・電子工学専攻 博士課程満了。同大学工学部助手, 同講師, 同 助教授を経て，1988 年同教授，現在に至る。フ ランス , グルノーブル原子核研究所およびカラ 么研究所客員研究員。プラズマ・核融合科学と 兴の応用に関する研究に従事。工学博士。プラ ズマ・核融合学会, 日本物理学会会員, 応用物 理学会会員, 米国物理学会会員。 